\title{
ANALISIS METODE KANO DAN OPTIMASI PADA LAYANAN WARUNG BAKSO
}

\author{
Analysis Of Cano Methods And Optimization On The Services Of Meat Shop \\ ${ }^{1}$ Mas Ayoe Elhias, ${ }^{2}$ Soeheri, ${ }^{3}$ Helmi Kurniawan \\ ${ }^{1,2}$ Dosen Jurusan Sistem Informasi Universitas Potensi Utama \\ ${ }^{3}$ Dosen Jurusan Informatika Universitas Potensi Utama \\ Universitas Potensi Utama \\ J1. K.L. Yos Sudarso Km. 6.5 No. 3 A - Medan, 20241, Indonesia

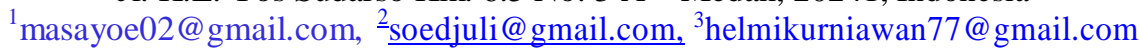

\begin{abstract}
Abstrak
Model Kano merupakan salah satu cara untuk mengetahui tingkat kepuasan konsumen terhadap pelayanan dan kualitas rasa makanan. Sedangkan metode optimasinya adalah dengan menghitung antrian yang ada di warung tersebut. Tujuan penelitian ini dibuat untuk mengetahui tingkat kualitas pelayanan warung dan menghitung berapa antrian yang harus dilayani setiap jamnya. Warung Bakso Ojo lali merupakan warung bakso umum yang mampu memberikan pelayanan dengan kualitas terbaik, sehingga tercipta kepuasan bagi para pelanggannya. Berbagai macam keluhan yang sering muncul baik di media cetak maupun dari pengamatan awal membuat analisis indikator kualitas pelayanan Bakso Ojo Lali menjadi penting untuk dilakukan. Penelitian ini bertujuan untuk mengetahui indikator kepuasan konsumen khususnya indikator mana yang paling berpengaruh terhadap kenaikan dan penurunan tingkat kepuasan. Penelitian ini merupakan penelitian deskriptif dengan menggunakan diagram Kano dan optimasi antrian untuk menganalisis dan mengkategorikan atribut-atribut kualitas pelayanan, berdasarkan seberapa baik tingkat pelayanan mampu memuaskan kebutuhan pelanggan Warung Bakso Ojo Lali. Hasil analisis nilai diagram Kano lebih baik dan terburuk diketahui atribut-atribut yang mempengaruhi peningkatan kepuasan pelanggan. Optimasi Antrian ini untuk mengetahui jumlah antrian yang ada dalam pelayana, dalam optimasi ini juga dapat diketahui waktu tunggu pelayanan yang akan diberikan kepada konsumen berdasarkan waktu pelayanan yang diberikan kepada masin-masing konsumen.Berdasarkan hasil analisis ini optimasi antrian dan analisis kano dapat diintegrasisikan menjadi satu kesatuan guna memperoleh kualitas pelayanan dan waktu pelayanan dalam antrian yang akan menghasilakan sebuah kualitas pelayanan.
\end{abstract}

Kata kunci- Layanan, Optimasi antrian, Kano.

\begin{abstract}
Kano model is one way to determine the level of customer satisfaction with service and quality of food taste. While the optimization method is to calculate the queue in the stall. The purpose of this study was to determine the level of service quality of the stalls and calculate how many queues must be served every hour. Warung Bakso Ojo lali is a general meatball stall that is able to provide the best quality service, so as to create satisfaction for its customers. Various kinds of complaints that often appear both in the print media and from initial observations make it important to analyze the service quality indicators of Bakso Ojo Lali. This study aims to determine the indicators of consumer satisfaction, especially which indicators have the most influence on the increase and decrease in the level of satisfaction. This research is a descriptive study using Kano diagrams and queue optimization to analyze and categorize service quality attributes, based on how well the service level is able to satisfy the customer needs of Warung Bakso Ojo Lali. The results of the analysis of the Kano diagram value are better and the worst known attributes that affect the increase in customer satisfaction. This Queue Optimization is to determine the number of queues in service, in this optimization it can also be seen the waiting time for services to be provided to consumers based on the service time provided to each customer. Based on the results of this analysis, queue optimization and canoe analysis can be integrated into one unity in order to obtain service quality and service time in the queue which will result in a quality service.
\end{abstract}

Keywords - Service, Queue optimization, Canoe 


\section{LATAR BELAKANG}

Seringkali kita melihat antrian dalam membeli makanan atau menunggu makanan diantarkan, ketika sebuah warung mengalami banyak konsumen. Hal ini terjadi bila tingkat keinginan dan kebutuhan yang sangat tinggi berasal dari konsumen. Untuk mempertahankan pelanggan pemilik usaha harus melakukan berbagai upaya dalam meningkatkan kualitas dan pelayanan yang diberikan kepada konsumen.

Kano adalah model yang menyajikan kualitas layanan dengan nilai yang dihasilkan dalam bentuk lebih buruk atau lebih baik. Dimana model ini bertujuan untuk mengkategorikan atribut layanan yang telah diberikan kepada konsumen. Kano membedakan berdasarkan tiga kategori diantaranya: Must menjadi persyaratan, persyaratan satu dimensi, persyaratan menarik. Must be adalah tipe paling dasar yang harus dimiliki dalam jasa atau barang. Jika kriteria ini tidak ada maka dipastikan konsumen tidak akan puas. Requerements satu dimensi merupakan atribut proporsional jika pemenuhan pelayanan kepada konsumen terpenuhi dan baik maka diperoleh komparatif maka kepuasan konsumen semakin tinggi. Persyaratan yang menarik merupakan atribut kunci dari kepuasan pelanggan, atribut tersebut jika dipenuhi maka akan mendapatkan keputusan yang tinggi dari konsumen, namun jika tidak terpenuhi maka konsumen tidak kecewa. Persyaratan ini tidak serta merta harus direalisasikan, namun jika pemilik bisnis menginginkan nilai yang baik dari konsumen, maka atribut ini perlu dipenuhi. Model Kano digunakan untuk menganalisis pengaruh kualitas pelayanan warung bakso terhadap konsumen, dan untuk mengetahui tingkat kepuasan konsumen. Dalam Kano terdapat 5 kategori yaitu must be, one dimenstional, atraktif, indifference, dan reverse yang masing-masing memiliki karakteristik dan pengaruh yang berbeda.

Model optimasi merupakan model antrian yang berguna sebagai perancangan sistem dalam pelayanan warung bakso. Pada layanan warung pasti akan terjadi peningkatan antrian pada jam-jam tertentu sehingga menyebabkan penumpukan antrian layanan. Tingginya kedatangan konsumen pada waktu tertentu yang tidak dapat diprediksi, sehingga perlu adanya desain layanan untuk memberikan efektivitas layanan.

Penelitian ini dilakukan untuk menggabungkan desain optimasi dengan sistem kepuasan pelanggan. Warung bakso ini dapat meningkatkan kualitas pelayanan kepada konsumen mulai dari rasa hingga pelayanan lainnya

Teori antrian di temukan pertama kali olek A.K Erlang oleh ahli matematika Denmark pada tahun 1910. Terbentuknya antrian jika banyaknya pelanggan yang akan dilayani melebihi kapasitassehingga terjadi situasi dimana pelanggan harus melakukan antrian untuk mendapatkan suatu layanan (Bronson, 1991). Proses antrian seperti Poisson yang sering terjadi dalam fasilitas pelayanan. Dalam antrian merupakan suatu proses yang berhubungan dengan kedatangan pelanggan dalam suatu fasilitas pelayanan, dan menunggu antrian untuk dilakukan pelayanan berikutnya. Pola antrian merupakan karakteristik suatu antrian yang ditentukan oleh unit maksimum yang boleh ada di dalam sistemnya yang terbatas maupun tidak terbatas. Struktur dasar model antrian dimulai dari sumber input ke antrian untuk mendapatkan pelayanan ke satuan dan akan dilayani dalam waktu berikutnya.

\section{METODOLOGI PENELITIAN}

Metode penelitian yang digunakan merupakan teknik atau cara untuk memgumpulkan data memalui pengumpulan data yang di tabulasi dan kemudian akan di uji data sehingga dapat dipecahkan dengan analisis metode yang digunakan dan disumulasikan dengan optimasi antirian. Metodologi Penelitian yang digunakan adalah sebagai berikut : 


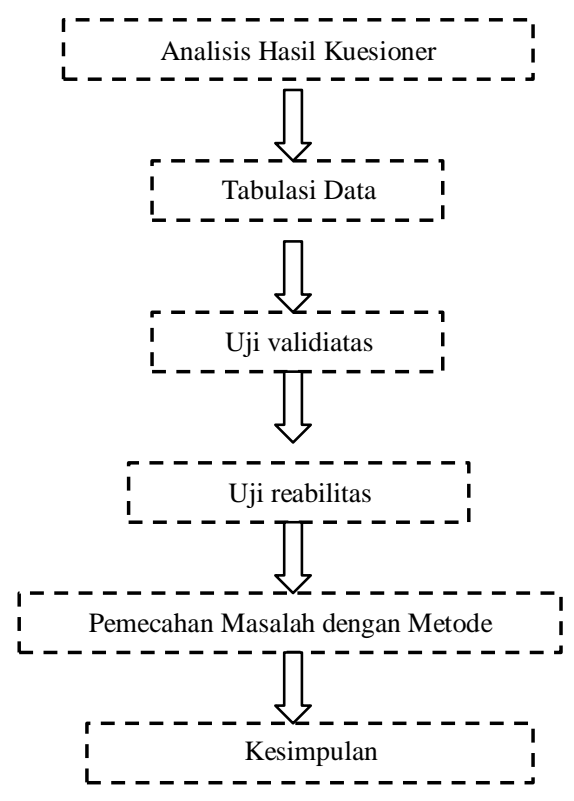

Gambar 1. Alur Penelitian

1. Analisa hasil Kuesioner

Koresponden atau pelanggan memberikan jawaban atas pelayanan warung yang diberikan, pelanggan dapat memberi komentar dan penilaian dengan skala likert yang telah ditentukan.

2. Tabulasi Data

Dari hasil data koresponden, maka data tersebut dilakukan tabulasi dan clusterisasi untuk memperoleh data yang akan dilakukan pengujian ketahap berikutnya.

3. Uji Validitas

Dalam tahap uji validitas ini adalah tahap melakukan pengujian data untuk mendapatkan nilai validasi yang akan diteruskan ke uji reabilitas, data yang di uji sesuai dengan instrument yang diberikan kepada responden.

4. Uji Reabilitas

Uji Reabilitas adalah tahap pengujian yang dilakukan setelah validitas tahap ini memastikan data sesuai dengan instrument yang diberikan, sehingga mendapatkan data yang paling valid untuk di proses ke dalam metode yang digunakan dalam penelitian ini.

5. Pemecahan Masalah dengan metode yang digunakan

Dari data uji reabilitas maka akan diproses dengan menggunakan metode Kano dan dilakukan simulasi optimasi antrian sehingga memeperoleh pemecahan masalah dan kesimpulan dari pelayanan yang diberikan apakah telah efektif

6. Kesimpulan

Setelah dari tahap pemecahan masalah maka akan diperoleh kesimpulan dan tindak lanjut dari pelayanan yang diberikan sehingga dapat meningkatkan mutu pelayanan warung berikutnya.

\section{HASIL DAN PEMBAHASAN}

\section{A. Analisis Kano}

Atribut Kategori yang digu nakan dalam KANO adalah sebagai berikut:

1. Must be, Pelanggan menjadi tidak puas jika atributnya rendah, Kepuasan pelanggan tidak akan meningkat meskipun kinerja atribut tinggi.

2. One Dimentional, tingkat kepuasan pelanggan berhubungan secara linier dengan atribut kinerja.

3. Attractive, tingkat kepuasan pelanggan akan meningkat, kinerja atribut akan meningkat.

4. Attractive quality elements, atribut ini menggambarkan kualitas interaksi dan atribut ini memberikan kepuasan ketika terpenuhi. 
5. Indifferent quality elements, atribut ini mengacu pada hal buruk atau tidak baik, kinerja nya tidak menghasilkan kepuasan kepada pengguna.

6. Reverse quality elements, atribut ini memiliki kinerja produk atau jasa yang tinggi, yang akan menghasilkan indeks kepuasan kepada penggunanya.

Dalam penelitian ini pertanyaan-pertanyaan pada kuesioner kepuasan pelanggan yang ditabulasi dan diukur menggunakan kano akan menghasilkan penilaian dengan ekspektasi baik atau buruk dengan skor penilaian.

Tabel 1. Range Penilaian

\begin{tabular}{|l|l|l|}
\hline Skala Likert & Deskripsi & Range Nilai \\
\hline 5 & Sangat Baik & $85-100$ \\
\hline 4 & Baik & $75-84.9$ \\
\hline 3 & Cukup & $74.9-65$ \\
\hline 2 & Kurang & $64.9-55$ \\
\hline 1 & Sangat Kurang & $54.9-0$ \\
\hline
\end{tabular}

Satifier adalah hal yang diinginkan konsumen yang terdapat pada produk atau jasa dan hal ini biasanya sering ditanyakan oleh konsumen, apabila sebuah kita menyediakan satifier ini maka konsumen akan semakin senang dan semakin loyalitas terhadap produk atau jasa yang diberikan. Didalam satifier ini terdapat desired quality karena akan menampilkan atau mempresentasikan nilai-nilai aspek dari produk yang diperoleh dari konsumen.

Tabel 2. Dimensi kualitas pelayanan

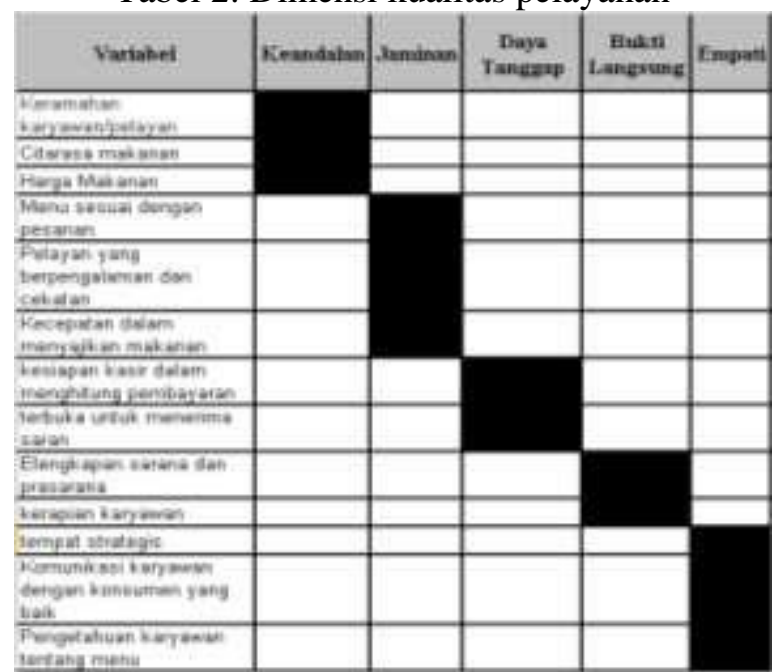

Perhitungan kepuasan pelanggan juga diiringi dengan rata-rata harapan pelanggan sehingga dapat diketahui gap (selisih) antara harapan dan kepuasan / fakta.

\section{Analisis Kesenjangan = Rata-rata Fakta - Rata-rata Harapan}

Jika gap positif, maka ekspektasi siswa masih lebih besar jika dibandingkan dengan fakta yang dirasakan, Sedangkan gap negatif berarti kepuasan dirasakan di atas harapan yang diinginkan 


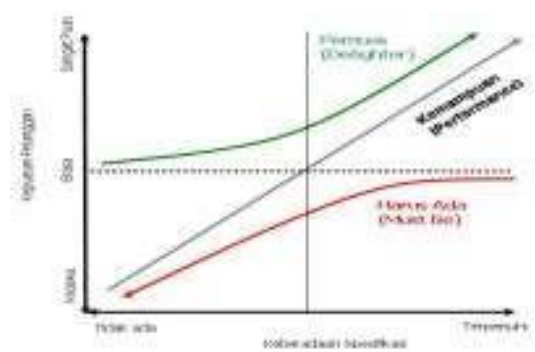

Gambar 2. Model Kano

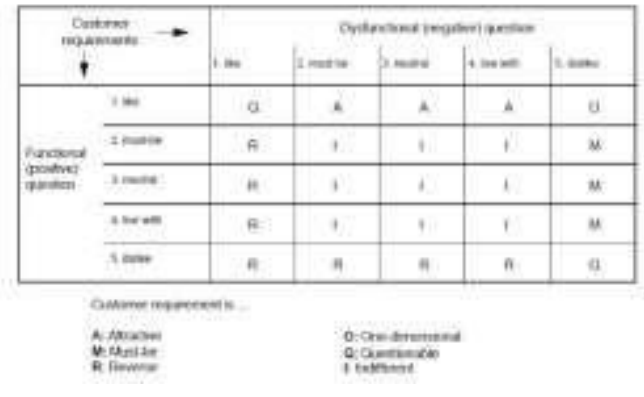

Gambar 3. Evaluasi kategori Kano berikut :

Dalam menentukan Atribut evaluasi kano dapat menggunakan Blauth's formula, sebagai

1. Jika (one-dimensional + attractive + must be $)>($ indefferent + reverse + questionable $)$, maka grade diperoleh dari yang paling maksimum dari one-dimensional, attractive, atau must-be.

2. Jika (one-dimensional + attractive + must be $)<($ indifferent + reverse + questionable $)$, maka grade diperoleh dari yang paling maksimum dari indifferent, reverse, atau questionable.

Rumus perhitungan dalam metode Kano adalah sebagai berikut:

\section{Better $\equiv \mathbf{A}+\mathbf{O}$ \\ $\mathrm{A}+\mathrm{O}+\mathrm{M}+\mathrm{I}$ \\ Worse $=-\mathbf{O}+\mathbf{M}$ \\ Keterangan \\ $\mathrm{A}+\mathrm{O}+\mathrm{M}+\mathrm{I}$}

$\mathrm{A}=$ Elemen kualitas yang menarik

$\mathrm{O}=$ Elemen kualitas satu dimensi

$\mathrm{M}=$ Elemen kualitas yang harus ada

$\mathrm{I}=$ Elemen kualitas biasa saja

Tabel 4. Nilai Responden

\begin{tabular}{|c|c|c|c|c|c|c|c|c|c|c|c|c|c|c|c|c|c|c|c|c|c|c|c|c|c|c|c|c|c|c|c|c|}
\hline \multirow{2}{*}{ Komponen } & \multirow{2}{*}{\multicolumn{2}{|c|}{ Pertanyaan }} & \multicolumn{30}{|c|}{ Respondea } \\
\hline & & & 1 & 2 & 3 & 4 & 5 & 6 & 7 & 8 & 9 & 10 & 11 & 12 & 13 & 14 & 15 & 6 & 17 & 18 & 19 & 20 & 21 & 22 & 23 & 24 & 25 & 26 & 27 & 28 & 29 & 30 \\
\hline & 1 & 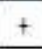 & 5 & 5 & 5 & 5 & 3 & 4 & 4 & 5 & & 4 & 4 & 4 & 4 & 3 & 5 & 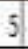 & 5 & 4 & 3 & 4 & 4 & 3 & 4 & 4 & 5 & 5 & 5 & 4 & 4 & 4 \\
\hline & & 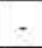 & 1 & 1 & 1 & 1 & 3 & 2 & 2 & 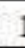 & & 2 & 2 & 2 & 2 & 3 & 1 & 1 & 1 & 2 & 3 & 2 & 2 & 3. & 2 & 2 & 1 & 1 & 1 & 2 & 2 & 2 \\
\hline & 2 & $t$ & 4 & 3 & 4 & 5 & 4 & 3 & 5 & 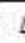 & & 4 & 5 & 4 & 4 & 5 & 4 & 4 & 5 & 3 & 4 & 4 & 5 & 4 & 3 & 4 & 3 & 4 & 5 & 4 & 4 & 4 \\
\hline & & - & 2 & 3 & 2 & 1 & 2 & 3 & 1 & 2 & & 3 & 1 & 2 & 2 & 1 & 2 & ? & 1 & 3 & 4 & 2 & 1 & 2 & 3 & 2 & 3 & 2 & 1 & 2 & 2 & \\
\hline & 3 & + & 5 & 4 & 4 & 5 & 3 & 5 & 3 & 5 & & 4 & 5 & 4 & 5 & 5 & 3 & 4 & 4 & 5 & 3 & 5 & 3 & 4 & 3 & 5 & 3 & 3 & 5 & 4 & 4 & 5 \\
\hline & & . & 1 & 2 & 2 & 1 & 3 & 1 & 3 & 1 & & 2 & 1 & 2 & 1 & 1 & 3. & 2 & 4 & 1 & 3 & 1 & 3 & 2 & 3. & 1 & 3 & 3 & 1 & 2 & 2 & 1 \\
\hline & 4 & + & 4 & 5 & 4 & 4 & 3 & 4 & 3 & f & & 4 & 3 & 3 & 4 & 4 & 3 & 4 & 4 & 3 & 4 & 4 & 4 & 3 & 3 & 4 & 3 & 3 & 4 & 4 & 4 & 4 \\
\hline & & . & 2 & 1 & 2 & 2 & 3 & 2 & 3 & 2 & & 2 & 3 & 3 & 2 & 2 & 3 & & 2 & 3 & 2 & 2 & 2 & 3 & 3 & 2 & 3 & 3 & 2 & 2 & 2 & 2 \\
\hline \multirow[b]{2}{*}{5} & 5 & + & 5 & 3 & 4 & 3 & 4 & 4 & 3 & 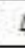 & & 3 & 5 & 3. & 5 & 5 & 4 & & 4 & 3 & 4 & 5 & 2 & 4 & 5 & 4 & 4 & 5 & 4 & 5 & 4 & 5 \\
\hline & & . & 1 & 3 & 2 & 3 & 2 & 2 & & 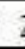 & & 3 & 1 & 3 & 1 & 1 & 2 & 2 & & 3 & 2 & 1 & 4 & 2 & 1 & 2 & 2 & 1 & 2 & 1 & & \\
\hline
\end{tabular}


Perhitungan Kriteria Harapan dan persepsi

Tabel 5. Tabel Nilai harapan, persepsi dan instrument

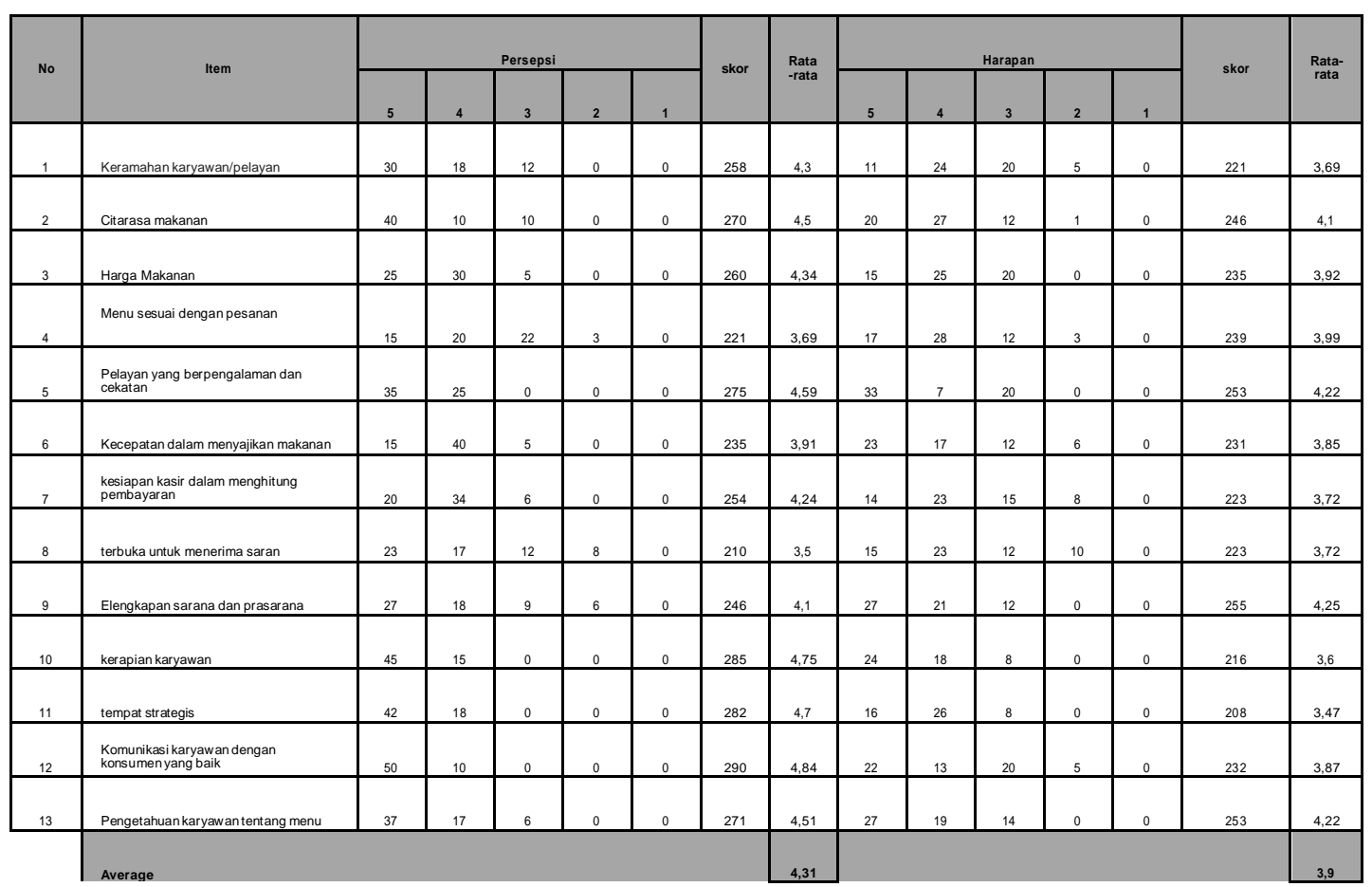

Akumulasi dan grade fungsional dan disfungsional dalam kano

Tabel 6. Tabel Grage fungsional dan di fungsional

\begin{tabular}{|c|c|c|c|c|c|c|c|c|c|}
\hline $\begin{array}{c}\text { CUST } \\
\text { REQUIR } \\
\text { EMENT }\end{array}$ & A & M & O & R & Q & I & TOTAL & MAX & GRADE \\
\hline 1 & 30 & 10 & 20 & 0 & 0 & 0 & 60 & 30 & A \\
\hline 2 & 21 & 8 & 23 & 5 & 0 & 3 & 60 & 23 & O \\
\hline 3 & 21 & 7 & 25 & 7 & 0 & 0 & 60 & 25 & O \\
\hline 4 & 30 & 3 & 24 & 3 & 0 & 0 & 60 & 30 & A \\
\hline 5 & 28 & 5 & 27 & 0 & 0 & 0 & 60 & 28 & A \\
\hline
\end{tabular}

Menghitung nilai BETTER \& WORSE

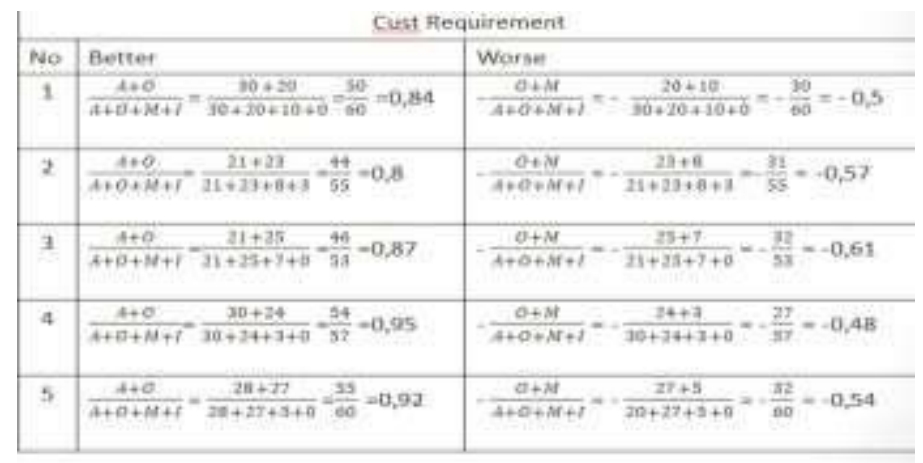

Gambar 4. Nilai Better dan Worse 
Setelah jumlahnya seperti tabel diatas, maka inilah hasil dari nilai Better \& Worse adalah sebagai berikut:

Nilai Hasil BETTER dan WORSE

\begin{tabular}{|c|c|c|c|c|c|c|c|c|c|}
\hline $\begin{array}{c}\text { Cust } \\
\text { Rrauiatemsnt }\end{array}$ & A & $M$ & $o$ & n & a & ' & Toral. & BrTIE & wonst \\
\hline 1 & 30 & 10 & 20 & 0 & 0 & c & 60 & b., ad & - a.s \\
\hline 2 & 21 & a & 27 & s & อ & z & 60 & $0, n$ & 0,57 \\
\hline 3. & 21 & 7 & 25 & 7 & 0 & o & 60 & 0,157 & 0,61 \\
\hline 4 & 30 & 3 & 24 & 3 & o & c & 60 & 0,95 & $0,4 \mathrm{~A}$ \\
\hline 5 & 200 & $s$ & zi & o & $o$ & d & 60 & 0.32 & 0.54 \\
\hline
\end{tabular}

Gambar 5. Nilai custumer Requirement

\begin{tabular}{|c|c|c|c|c|c|c|}
\hline \multirow{2}{*}{\multicolumn{2}{|c|}{$\begin{array}{l}\text { Customer } \\
\text { Requirement }\end{array}$}} & \multicolumn{5}{|c|}{ Dysfunctional } \\
\hline & & \multirow{2}{*}{$\begin{array}{r}\text { 1. Lke } \\
\text { a }\end{array}$} & \multirow{2}{*}{$\begin{array}{c}\text { 2Must-be } \\
\text { A }\end{array}$} & \multirow{2}{*}{ 3.Neutral } & \multirow{2}{*}{$\begin{array}{l}\text { 4. Wive } \\
\text { with } \\
\text { A }\end{array}$} & \multirow{2}{*}{$\begin{array}{c}\text { 5.0isilike } \\
0\end{array}$} \\
\hline \multirow{5}{*}{ functional } & Like & & & & & \\
\hline & 2.Must. & R & 1 & 1 & 1 & M \\
\hline & 3.Neutral & R & 1 & 1 & 1 & M \\
\hline & 4.Jve & R & 1 & 1 & 1 & M \\
\hline & 5.Dislke & $\mathrm{R}$ & R & R & $R$ & 0 \\
\hline & & & & & & \\
\hline
\end{tabular}

Gambar 6. Gambar Skala Fungsional dan disfungsional

Berdasarkan gambar diatas akan memberikan suatu kesimpulan pelayanan bahwa kebutuhan pelanggan bersifat fungsional dan memiliki nilai like, artinya sangat suka. Apabila tingkat nilai kepuasan mencapai atau mendekati nilai 1, maka dapat disimpulkan atribut tersebut semakin mempengaruhi kepuasan konsumen. Apabila nilai semakin mendekati 0, maka atribut tersebut tidak mempengaruhi penjual. Namun apabila tingkat kekecewaan mendekati nilai -1, maka pengaruh kekecewwaan akan semakin kuat apabila atribut tersebut tidak terpenuhi dan apabila mendekati nilai 0 maka atribut tersebut terpenuhi dan apabila mendekati 0 maka atribut tersebut tidak berpengaruh terhadap kekecewaan konsumen.

B. Analisis Optimasi Antrian

Secara umum proses antrian pelayanan bakso dapat dijelaskan sebagai berikut

1. Sebuah Warung Bakso memiliki 2 orang pelayan untuk menerima pesanan, dan 2 orang untuk membuat makanan yang dipesan.

2. Kapasitas antrian tidak terbatas

3. Sistem antriannya adalah FIFO pertama (first in First Out) yang akan dilayani terlebih dahulu.

4. Konsumen datang langsung untuk memesan, bagi yang tidak makan di tempat.

5. pramusaji akan mencatat pesanan, selanjutnya akan dibuat oleh pramusaji berikutnya untuk dibungkus atau disajikan di tempat.

6. Kemudian konsumen menerima pesanan tersebut, dan melakukan pembayaran di kasir. 
Tabel 7. Tabel nilai kedatangan dan pelayanan

\begin{tabular}{|c|c|}
\hline Waktu antar Kedatangan & Service Time \\
\hline 1 & 1 \\
\hline 3 & 1 \\
\hline 2 & 0.45 \\
\hline 5 & 0.30 \\
\hline 3 & 1.5 \\
\hline 2 & 1 \\
\hline 2 & 2 \\
\hline 5 & 1.5 \\
\hline 5 & 2 \\
\hline 4 & 2 \\
\hline 2 & 1 \\
\hline 5 & 1 \\
\hline 4 & 0.45 \\
\hline 3 & 1 \\
\hline 2 & 0.30 \\
\hline 1 & 1.5 \\
\hline 2 & 1 \\
\hline 3 & 0.45 \\
\hline 2 & 1 \\
\hline 2 & 2 \\
\hline 7 & 1.25 \\
\hline 3 & 1 \\
\hline 2 & 1.5 \\
\hline 3 & 1.5 \\
\hline 1 & 1 \\
\hline 3 & 1 \\
\hline 3 & 0.45 \\
\hline 3 & 22 \\
\hline 4 & 1 \\
\hline 4 & 0.30 \\
\hline 2 & 1.25 \\
\hline 4 & 1 \\
\hline 2 & 0.45 \\
\hline 3 & 1 \\
\hline 2 & 1.5 \\
\hline 4 & 2 \\
\hline 4 & 1.25 \\
\hline 5 & 1.50 \\
\hline 3 & 1 \\
\hline 2 & 1.30 \\
\hline 5 & 1 \\
\hline 4 & 1.50 \\
\hline 7 & 1 \\
\hline 6 & 1.25 \\
\hline 3 & 1 \\
\hline 2 & 0.30 \\
\hline 3 & 1 \\
\hline 2 & 0.45 \\
\hline 4 & 1 \\
\hline 2 & 1.25 \\
\hline
\end{tabular}

Data diatas merupakan data waktu kedatangan konsumen dengan waktu pelayanan, data tersebut diperoleh dari observasi. 
Tabel 8. Tabel nilai Probabilitas Distribusi

\begin{tabular}{|c|c|c|c|c|}
\hline $\begin{array}{l}\text { Service } \\
\text { Time }\end{array}$ & $\begin{array}{l}\text { Cumulative } \\
\text { Frequency }\end{array}$ & $\begin{array}{l}\text { Relative } \\
\text { Frequency }\end{array}$ & $\begin{array}{l}\text { Relative } \\
\text { Probability }\end{array}$ & $\begin{array}{l}\text { Cumulative } \\
\text { Probability }\end{array}$ \\
\hline \multirow{2}{*}{$\begin{array}{l}1 \\
2\end{array}$} & 2,5 & \multirow{2}{*}{$\begin{array}{l}2,5 \\
7,5 \\
\end{array}$} & 0,05 & \multirow{2}{*}{$\begin{array}{c}0,05 \\
0,2 \\
\end{array}$} \\
\hline & 10 & & 0,15 & \\
\hline 3 & 24,5 & \multirow{5}{*}{$\begin{array}{c}14,5 \\
15,5 \\
7,5 \\
2,5 \\
1\end{array}$} & 0,29 & \multirow{2}{*}{$\begin{array}{c}0,49 \\
0,8\end{array}$} \\
\hline 4 & 40 & & 0,31 & \\
\hline 5 & 47,5 & & 0,15 & 0,95 \\
\hline 6 & \multirow{2}{*}{$\begin{array}{l}50 \\
50\end{array}$} & & \multirow[t]{2}{*}{0,05} & 1 \\
\hline Jumlah & & & & \\
\hline
\end{tabular}

\section{KESIMPULAN}

Dalam hasil penelitian ini maka diperoleh kesimpulan dari nilai pelayanan yang diberikan dengan analisis kano bahwa pelayanan diberikan sangat baik, sesuai dengan tabel di bawah ini.

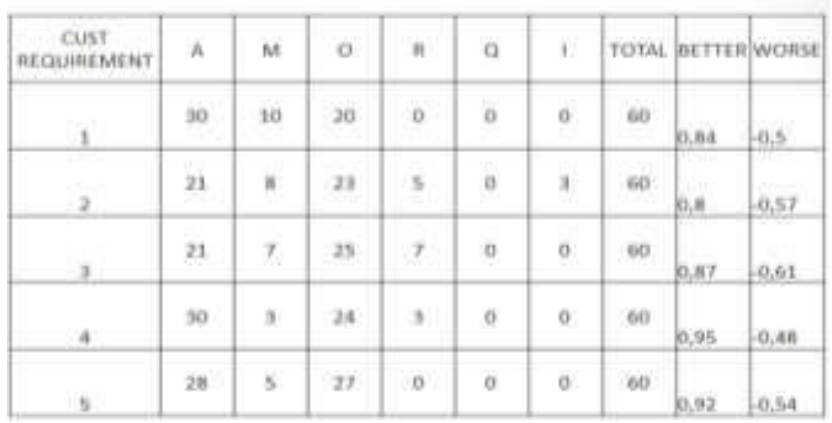

Gambar 7. Tabel Perhitungan Kano

Hasil dari nilai pelayanan yang diberikan warung bakso kepada konsumen.

Tabel 9. Tabel Waktu Pelayanan

\begin{tabular}{|c|c|c|c|c|c|}
\hline $\begin{array}{c}\text { Service Time } \\
\text { ( Minutes ) }\end{array}$ & $\begin{array}{l}\text { Relative } \\
\text { Probability }\end{array}$ & $\begin{array}{l}\text { Cumulative } \\
\text { Probability }\end{array}$ & \multicolumn{3}{|c|}{$\begin{array}{l}\text { Random Digits } \\
\text { Assigment }\end{array}$} \\
\hline 1 & 0,05 & 0,05 & 0 & To & 4 \\
\hline 2 & 0,15 & 0,20 & 5 & To & 19 \\
\hline 3 & 0,29 & 0,49 & 20 & To & 48 \\
\hline 4 & 0,31 & 0,80 & 49 & To & 79 \\
\hline 5 & 0,15 & 0,95 & 80 & To & 94 \\
\hline 6 & 0,05 & 1,00 & 95 & To & 99 \\
\hline
\end{tabular}

Dari tabel di atas waktu kedatangan dicari distribusi waktu pelayanan yaitu: 0, -4,5-19, 20-48, 4979, 80-94, 95-99.

Berdasarkan hasil penelitian ini sistem pelayanan yang diberikan kepada konsumen, sehingga warung bakso mengetahui kualitas yang diberikan kepada konsumen, tingkat kepuasan pada jabatan fungsional dan produksi satu dimensi. Dalam menggunakan perhitungan optimasi antrian diketahui waktu pelayanan per menit sebanyak 50 pelanggan. 


\section{SARAN}

Saran yang dapat penulis berikan terhadap penelitian ini, berharap dapat terus meningkatkan pelayanan yang diberikan dan waktu pelayanan yang sudah cukup baik dalam melakukan antrian dalam warung ini. Berikutnya mungkin penelitian ini sebagai pengembangan untuk penelitian berikutnya, untuk memperoleh hasil yang lebih baik.

1. Optimasi antrian diintegrasikan bersamaan dengan analisis kano sehingga memperoleh hasil yang maksimal dari aspek pelayanan dan waktu antrian.

2. Terdapat 13 fungsionalitas sistem pelayanan yang diberikan dalam mengggunakan analisis kano, sehingga memperoleh hasil apakah better atau worse berdasarkan atribut, must be, one dimentional, dan lainnya.

\section{REFERENCES}

[1] Nunung Nurhasanah, 2015, Simulasi Flexim untuk Optimasi Sistem Antrian Poli Umum Rawat jalan Rumah Sakit X, Jurnal ilmiah Teknik Industri, vol 3 No.2: 69-75.

[2] Widya Setia Findari, 2019, Optimasi Sistem Antrian Pada Layanan Kesehatan Masyarakat Menggunakan Pendekantan Simulasi, Jurnal Manajemen Industri dan Logistik, Vol.3 No. 1: $14-22$

[3] Ade Selvia Septiani, 2017, Gambaran Sistem Antrian Pasien dalam Optimasi pelayanan di Loket Pendaftaran Intalasi Rawat Jalan Rumah sakit Umum Fatamawati, Jurnal Kesehatan Masyarakat, Vol.5 No.4

[4] Endah Utami, 2015, Pendekatan Model Kano pada Quality Function Deployment untuk Perbaikan Kualitas Kegiatan Belajar Mengajar, Jurnal Ilmiah TeknikIndustri, Vol.14 No.2.

[5] G.Arun Kumar, 2016, Design and Application of New Quality Improvement Model: Kano Lean Six Sigma for Software Maintanance Project, Arab J Sci Eng, 41: 997-1014.

[6[ Azham Hussain, 2015, Eliciting User Satisfiying Requirements For An e-Health Awareness System Using Kano Model, Recent Advances in Cumpoter Science, ISBN : 978-1-61804-2972

[7] Aulia Bayu Yushila, 2017, Analisis Kepuasan Konsumen dengan Metode Fuzzy Servqual dan Quality Function Deployment, Jurnal Teknologi pertanilan, Vol.18 No.2: 107-118.

[8] Edi Rustam Aji, 2016, Pengembngan Produk Lampu Meja Belajar dengan Metode Kano dan Quality Function Deployment (QFD), Jurnal Of Research and Technology, Vol.2 No. 2 EISSN:2477-6165

[9] Hasan Mastrisiswadi, 2016, Analisis Kebutuhan Robot Rehabilitasi pasien pasca stroke dengan menggunakan metode Kano, Jurnal Ilmiah Teknik Industri, Vo.15 No.2 :151-156 E-ISSN: $2460-4038$

[10] Kartika Botutihe, 2018, Analisis Sistem Antrian Teller guna Optimalisasi Pelayanan Pada PT. Bank Negara Indonesia (BNI) 46 Cabang Unit Kampus Manado, Jurnal EMBA, Vol.6 No.3: 1388-1397, ISSN 2303-1174 